\title{
Analisis Faktor-Faktor Yang Mempengaruhi Penerimaan Pph Pasal 21 Badan Padakantor Pelayanan Pajak Pratama Binjai
}

\author{
Illal Nurhabibah \\ Universitas Muhammadiyah Sumatera Utara \\ Dibie080819@gmail.com
}

\author{
Eka Nurmalasari \\ Universitas Muhammadiyah Sumatera Utara \\ ekanurmala@umsu.ac.id \\ Widia Astuty \\ Universitas Muhammadiyah Sumatera Utara \\ widiaastuty@umsu.ac.id
}

https://doi.org/10.30596/jrab.v21i1.6756

\section{ABSTRACT}

The type of data used in this study is secondary data and time series data. This study uses data from the past five years, namely the period 2014-2019 obtained from Badan Pusat Statistik (BPS) of Binjai City and KPP Pratama Kota Binjai. Data were analyzed using multiple linear regression models. The results of the study show that: (1) The amount of tax with holding has a negative effect and not signicant the income of PPh Article 21. (2) Gross Regional Domestic Product (GRDP) has a positive effect and significant on the receipt of PPh Article 21 Agency. (3) The number of Population has a positive effect and significant on the receipt of PPh article 21 Agency. (4) The number of the Work Force has a negative effect and significant on the receipt of PPh Article 21 Agency. (5) The amount of Tax Withholding, Gross Regional Domestc Product (GRDP), The number of population, and the number of the Work Force simultaneously affect on the receipt of PPh Article 21 Agency.

$$
\begin{gathered}
\text { Keyword : Withholding Tax, Gross Regional Domestic Product (GRDP), Population, Receipt PPh } \\
\text { article }
\end{gathered}
$$

Cara Sitasi : Nurhabibah, I., Nurmalasari, E., Astuty, W. (2021). Analisis Faktor-Faktor Yang Mempengaruhi Penerimaan Pph Pasal 21 Badan Padakantor Pelayanan Pajak Pratama Binjai. Jurnal Riset Akuntansi dan Bisnis, vol.21.(1), hal 129- 136 https://doi.org/10.30596/jrab.v21i1.6756

\section{PENDAHULUAN}

Pajak merupakan kontribusi atau iuran rakyat kepada kas Negara berdasarkan undang-undang, sebagai perwujudan pengabdian dan peran serta rakyat untuk membiayai negara dan pembangunan nasional (Dwi Sunar Prasetyono, 2011). Wajib pajak adalah orang pribadi atau badan yang menurut ketentuan peraturan perundang-undangan perpajakan ditentukan untuk melakukan kewajiban membayar pajak, termasuk sebagai pemungut pajak atau pemotong pajak tertentu. Wajib pajak badan mempunyai penghasilan dari beberapa 


\section{Jurnal Riset Akuntansi dan Bisnis}

Vol 21 No.1 Tahun, 2021 hal 129 - 136

ISSN 1693-7597 (Print), 2623-2650 (online)

Available online: http://jurnal.umsu.ac.id/index.php/akuntan

sumber penghasilan. Pertama, dari usaha atau kerjaan bebas yang menyelenggarakan pembukuan atau norma penghitungan penghasilan netto. Kedua, dari satu atau lebih pemberi kerja. Ketiga, yang dikenakan PPh Final atau bersifat final. Keempat dari penghasilan lainnya.Pajak Penghasilan Pasal 21 yaitu gaji, upah, tunjangan, honorarium, komisi, bonus, gratifikasi, uang pensiun atau imbalan dalam bentuk lainnya termasuk penerimaan berupa pembayaran berkala, sehubungan dengan pekerjaan atau jabatan, jasa, dan kegiatan yang dilakukan oleh Orang Pribadi dalam negeri. Pajak Penghasilan Pasal 21 dikenakan melalui pemotong pajak dari penghasilan yang diterima atau diperoleh Orang Pribadi dalam negeri. Salah satu unit kerja Direktorat Jenderal Pajak yaitu berada di Kantor Pelayanan Pajak (KPP) Pratama Kota Binjai. KPP Pratama Kota Binjai beralamat di Jalan Jambi No. 1, Rambung Barat, Binjai. KPP Pratama Binjai bertugas secara langsung dalam mengawasi dan menangani pajak penghasilan di Kota Binjai.

Menurut Purwiyanto dan Tity Hernawati (2002: 71), tinggi rendahnya penerimaan pajak berkaitan dengan makro ekonomi seperti, pertumbuhan ekonomi, tingkat inflasi, jumlah penduduk, investasi, dan angkatan kerja. Hal ini terjadi karena variabel-variabel tersebut selain menjadi asumsi penting dalam menyusun kerangka kebijakan ekonomi termasuk sektor penerimaan perpajakan juga mempunyai pengaruh terhadap aktivitas kegiatan perekonomian.Salah satu fenomena kegiatan ekonomi suatu daerah adalah faktor Produk Domestik Regional Bruto (PDRB) perkapita penduduk di suatu daerah. Produk Domestik Regional Bruto (PDRB) perkapita adalah besarnya pendapatan rata-rata penduduk di suatu daerah. Produk Domestik Regional Bruto (PDRB) perkapita didapatkan dari hasil pembagian pendapatan nasional suatu daerah dengan jumlah penduduk daerah tersebut. Berdasarkan teori perpajakan, Musgrave (1989) besar kecilnya penerimaan di sektor pajak sangat ditentukan oleh jumlah penduduk, sehingga dikatakan bahwa jumlah penduduk berpengaruh terhadap penerimaan pajak daerah. Jumlah penduduk di Kota Binjai sendiri mengalami peningkatan mulai tahun 2015 hingga tahun 2018. Menurut Badan Pusat Statisitik yang menyatakan bahwa jumlah penduduk Kota Binjai Tahun 2015 sebesar 264.687 jiwa meningkat 267.901 jiwa pada tahun 2016 serta meningkat pada tahun selanjutnya yakni sebesar 270.926 jiwa pada tahun 2017 dan mengalami peningkatan jumlah penduduk menjadi sebesar 273.892 jiwa pada tahun 2018. Namun, pada tahun 2019, jumlah penduduk mengalami penurunan menjadi 271.251 jiwa. Dalam populasi penduduk yang besar terdapat penduduk usia produktif yang mampu menghasilkan barang atau jasa. Hal ini memacu adanya peningkatan penerimaan pajak terutama pajak penghasilan ( $\mathrm{PPh}$ pasal 21). Karena penduduk usia produktif akan memperoleh penghasilan, gaji atau upah atas barang atau jasa yang dihasilkan. Namun, peningkatan/pertambahan penduduk terutama usia produktif masih belum mampu untuk memacu tercapainya target pajak terutama penerimaan PPh 21. Hal ini dilihat dari ketersediaan lapangan pekerjaan yang tidak diimbangi dengan pertambahan penduduk.

Penelitian ini merupakan replikasi dari penelitian Aprilia Dwi Pratiwi dalam penelitiannya pada tahun 2018 yang berjudul "Analisis Faktor-Faktor Yang Mempengaruhi Penerimaan Pajak Penghasilan (PPh) Badan Diprovinsi Lampung". Namun demikian terdapat beberapa perbedaan dengan penelitian sebelumnya tersebut dengan penelitian ini. Adapun perbedaan yang dimaksud, antara lain variabel yang digunakan dalam penelitian sebelumnya tidak memakai angkatan kerja sebagai variabel bebas sedangkan dalam penelitian ini ada penambahan variabel independen yang mempengaruhi penerimaan pajak, yaitu jumlah pemotong pajak. Penelitian sebelumnya mengambil lokasi penelitian di Kota Lampung, sedangkan dalam penelitian ini di Kota Binjai. Penelitian sebelumnya dilakukan pada tahun 2018, sedangkan penelitian ini dilakukan pada tahun 2019. Berdasarkan 


\section{Jurnal Riset Akuntansi dan Bisnis}

Vol 21 No.1 Tahun, 2021 hal 129 - 136

ISSN 1693-7597 (Print), 2623-2650 (online)

Available online: http://jurnal.umsu.ac.id/index.php/akuntan

penelitian yang telah dilakukan oleh beberapa peneliti tersebut, peneliti tertarik melakukan penelitian mengenai

\section{KAJIAN TEORI \\ Pajak Penghasilan}

Pajak Penghasilan adalah pajak yang dibebankan atas penghasilan perorangan, perusahaan atau Badan Hukum lainnya. Pajak penghasilan pertama kali diatur dalam Undang-Undang No.7 tahun 1983 tentang Pajak Penghasilan yang kemudian dalam perkembangannya Undang-undang ini dilakukan perubahan beberapa kali yaitu periode tahun 1990, 1994, 2000 dan terakhir diubah pada tahun 2008. Menurut Pasal 1 Undangundang PPh, Pajak Penghasilan adalah pajak yang dikenakan terhadap subjek pajak atas penghasilan yang diterima atau diperolehnya dala tahun pajak. Dalam rumusan pasal tersebut dapat diperoleh pengertian bahwa suatu subjek pajak dikenakan pajak apabila menerima atau memperoleh penghasilan, yang kemudian disebut sebagai Wajib Pajak.

\section{Produk Domestik Regional Bruto (PDRB)}

Produk Domestik Bruto (PDRB) adalah total nilai produk barang dan jasa yang diproduksi di suatu wilayah tertentu dalam waktu tertentu tanpa melihat faktor kepemilikan. Salah satu model yang menunjukkan bagaimana pertumbuhan persediaan modal, pertumbuhan angkatan kerja dan kemajuan teknologi berinteraksi dalam perekonomian serta bagaimana pengaruhnya terhadap output barang dan jasa (PDRB) suatu wilayah secara keseluruhan adalah Model Solow (Mankiw, 2006). Produk Domestik Regional Bruto (PDRB) menurut Badan Pusat Statistik (BPS) didefinisikan sebagai jumlah nilai tambah yang dihasilkan oleh seluruh unit usaha dalam suatu wilayah, atau merupakan jumlah seluruh nilai barang dan jasa akhir yang dihasilkan oleh seluruh unit ekonomi di suatu wilayah.

\section{Penduduk}

Lembaga BPS dalam Statistik Indonesia (2013) menjabarkan "penduduk adalah semua orang yang berdomisili di wilayah geografis Republik Indonesia selama 6 bulan atau lebih dan atau mereka yang berdomisili kurang dari 6 bulan tetapi bertujuan untuk menetap". Sedangkan menurut Said (2012: 136) yang dimaksud dengan penduduk adalah "jumlah orang yang bertempat tinggal di suatu wilayah pada waktu tertentu dan merupakan hasil dari proses-proses demografi yaitu fertilitas, mortalitas, dan migrasi”.

\section{Angkatan Kerja}

Angkatan kerja adalah bagian dari tenaga kerja yang sesungguhnya terlibat, atau berusaha untuk terlibat dalam kegiatan produktif yang memproduksi barang dan jasa. Tenaga kerja (man power) adalah penduduk dalam usia kerja. Dalam literatur biasanya adalah seluruh penduduk berusia 15-64 tahun. Tetapi kebiasaan yang dipakai di Indonesia adalah seluruh penduduk berusia 10 tahun ke atas (hasil sensus penduduk 1971 dan 1980). Jadi, tenaga kerja (man power) adalah seluruh penduduk dalam usia kerja (berusia 15 tahun atau lebih) yang potensial dapat memproduksi barang dan jasa.

\section{Penerimaan Pajak Pasal 21}

Menurut Timbul dan Imam (2012:30) penerimaan negara dari pajak merupakan salah satu komponen penting dalam rangka kemandirian pembiayaan pembangunan. Sedangkan menurut Suryadi (2006:105) penerimaan pajak merupakan pembiayaan negara yang 


\section{Jurnal Riset Akuntansi dan Bisnis}

Vol 21 No.1 Tahun, 2021 hal 129 - 136

ISSN 1693-7597 (Print), 2623-2650 (online)

Available online: http://jurnal.umsu.ac.id/index.php/akuntan

dominan baik untuk belanja rutin maupun pembangunan. Berdasarkan pendapat para ahli, disimpulkan bahwa penerimaan pajak merupakan komponen dalam pembiayaan negara dan berjalannya arus belanja rutin negara dan pembangunan.

\section{Jumlah Pemotong Pajak Berpengaruh terhadap Penerimaan PPh 21 Badan}

Wajib Pajak Badan adalah Badan seperti yang dimaksud pada UU KUP, meliputi pembayar pajak, pemotong pajak, dan pemungut pajak, yang mempunyai hak dan kewajiban perpajakan sesuai dengan ketentuan peraturan perundang-undangan perpajakan atau memiliki kewajiban subjektif dan kewajiban objektif serta telah mendaftarkan diri untuk memperoleh Nomor Pokok Wajib Pajak (NPWP). Ada beberapa jenis Surat Pemberitahuan (SPT) Tahunan: Wajib Pajak Badan dan Wajib Pajak Orang Pribadi. Surat Pemberitahuan (SPT) Tahunan Badan merupakan Surat Pemberitahuan untuk suatu tahun pajak atau bagian tahun pajak yang disampaikan oleh Badan. N Didukung dengan penelitian terdahulu yang dilakukan Putro Asdora (2014), dimana memperoleh bahwa Jumlah SPT yang digunakan oleh pemotong pajak berpengaruh positif terhadap penerimaan pajak.

\section{Produk Domestik Regional Bruto (PDRB) berpengaruh terhadap Penerimaan PPh 21 Badan}

Meningkatnya Produk Domistik Regional Bruto (PDRB) terjadi akibat dari meningkatnya aktifikas perekonomian suatu daerah. Aktifitas perekonomian meningkat berpengaruh terhadap pendapatan masyarakat. Semakin meningkatnya pendapatan, jumlah harta/kekayaan dan besarnya pengeluaran masyarakat maka semakin tinggi kemampuan dalam membayar pajak terutama pajak penghasilan. Namun PDRB Perkapita dipengaruhi jumlah penduduk, jumlah penduduk dapat memberikan dampak positif dan negatif, PDRB Perkapita itu sendiri rata- rata pendapatan yang dihasilkan oleh setiap penduduk selama satu tahun di suatu wilayah/daerah. Hal ini juga sesuai dengan penelitian yang dilakukan oleh Muhammad Ikhsan Nasution (2017) memperoleh bahwa PDRB berpengaruh positif dan signifikan terhadap penerimaan pajak.

\section{Jumlah Penduduk berpengaruh terhadap Penerimaan PPh 21 Badan}

Sesuai dengan Teori Pertumbuhan Klasik yang di pelopori oleh Adam smith, David Ricardo, Maltus, dan John Stuart Mill menurut teori ini pada mulanya pertambahan penduduk akan menyebabkan kenaikan pendapatan perkapita. Tetapi apabila jumlah penduduk terus meningkat melebihi titik optimal maka pertumbuhan penduduk akan menyebabkan penurunan nilai pertumbuhan ekonomi. Dengan adanya aktifitas penduduk juga dalam perekonomian juga dapat berpengaruh terhadap penerimaan pajak. Dengan adanya jumlah penduduk yang meningkat, maka penerimaan pajak juga akan meningkat karena terjadi peningkatan jumlah penduduk usia produktif di dalam perekonomian. Hal ini juga sesuai dengan penelitian yang dilakukan oleh Muhammad Ikhsan Nasution (2017), Dian Purnama Sari (2016) memperoleh bahwa Penduduk berpengaruh terhadap penerimaan PPh pasal 21.

\section{Jumlah Angkatan Kerja berpengaruh terhadap Penerimaan PPh 21 Badan}

Pertumbuhan angkatan kerja di Indonesia diikuti dengan baik oleh pertumbuhan jumlah yang bekerja. Semakin banyak jumlah yang bekerja diharapkan dapat meningkatkan jumlah orang wajib pajak. Dengan adanya pertambahan angkatan kerja yang memperoleh pekerjaan, maka akan memberikan peningkatan penerimaan $\mathrm{PPh}$ pasal 21. Menurut 


\section{Jurnal Riset Akuntansi dan Bisnis}

Vol 21 No.1 Tahun, 2021 hal 129 - 136

ISSN 1693-7597 (Print), 2623-2650 (online)

Available online: http://jurnal.umsu.ac.id/index.php/akuntan

Muhammad Ikhsan Nasution (2017), bahwa jumlah orang bekerja berpengaruh positif dan signifikan terhadap penerimaan pajak

\section{METODE}

Jenis penelitian yang digunakan dalam penelitian ini adalah penelitian asosiatif. Menurut Sugiyono (2017:63) penelitian ini bertujuan untuk mengetahui pengaruh ataupun hubungan antara dua variabel atau lebih. Penelitian ini mengacu pada hubungan mengacu pada hubungan kausal dimana menunjukkan hubungan yang bersifat sebab akibat dengan menunjukkan adanya variabel independen dan dependen. Penelitian ini menggunakan rancangan penelitian berdasarkan prosedur statistik yang pengolahannya dibantu dengan aplikasi software SPSS 22. Sumber data yang digunakan dalam penelitian ini adalah data sekunder.

\section{HASIL DAN PEMBAHASAN}

Analisis Regresi Berganda

Coefficients $^{a}$

\begin{tabular}{|c|c|c|c|c|c|c|}
\hline \multirow{2}{*}{\multicolumn{2}{|c|}{ Model }} & \multicolumn{2}{|c|}{ Unstandardized Coefficients } & \multirow{2}{*}{$\begin{array}{c}\begin{array}{c}\text { Standardized } \\
\text { Coefficients }\end{array} \\
\text { Beta }\end{array}$} & \multirow[b]{2}{*}{$\mathrm{t}$} & \multirow[b]{2}{*}{ Sig. } \\
\hline & & $\mathrm{B}$ & Std. Error & & & \\
\hline \multirow[t]{5}{*}{1} & (Constant) & $-5,993 E+10$ & $1,372 \mathrm{E}+10$ & & $-4,368$ &, 000 \\
\hline & PDRB & 1655276,464 & 85138,920 & 938 & 19,442 &, 000 \\
\hline & Jumlah Penduduk & 130006,332 & 60641,475 & 126 & 2,144 & 036 \\
\hline & Jumlah Angkatan Kerja & $-2196334,625$ & 822333,384 &,- 159 & $-2,671$ &, 010 \\
\hline & Jumlah Pemotong Pajak & $-937128,018$ & 1196570,733 &,- 039 &,- 783 & 437 \\
\hline
\end{tabular}

a. Dependent Variable: Jumlah Penerimaan Pajak

Sumber: data olahan peneliti 2020

Berdasarkan hasil pengujian pada tabel diatas maka dapat disimpulkan:

1. Nilai konstanta sebesar -59928760102 yang artinya jika nilai Jumlah Pemotong Pajak, PDRB, Penduduk dan Angkatan Kerja bernilai 0, maka Penerimaan Pajak PPh pasal 21 Badan bernilai -59928760102. Dimana tanda negarif disini menunjukkan Penerimaan PPh pasal 21 Badan yang mengalami penurunan/terutang. Selain itu, nilai konstanta negatif (59928760102) diartikan juga bahwa rata-rata kontribusi variabel lain di luar model memberikan dampak negatif terhadap Penerimaan $\mathrm{PPh}$ pasal 21 Badan.

2. Jika nilai variabel Jumlah Pemotong Pajak $(\mathrm{X} 1)=1$ dengan asumsi variabel lainnya tetap atau bernilai 0 maka variabel Jumlah Pemotong Pajak (X1) berkontribusi terhadap Penerimaan PPh 21 Badan sebesar - 937128. Jika Jumlah Pemotong Pajak meningkat 1\% maka Penerimaan PPh 21 Badan menurun sebesar -937128.

3. Jika nilai variabel PDRB $(X 2)=1$ dengan asumsi variabel lainnya tetap atau bernilai 0 maka variabel variabel PDRB (X2) berkontribusi terhadap Penerimaan PPh 21 Badan sebesar 1655276. Jika PDRB meningkat 1\% maka Penerimaan PPh 21 Badan meningkat sebesar 1655276. Sebaliknya jika PDRB menurun 1\%, maka Penerimaan PPh 21 Badan menurun sebesar 1655276.

4. Jika nilai variabel Jumlah Penduduk $(X 3)=1$ dengan asumsi variabel lainnya tetap atau bernilai 0 maka variabel Jumlah Penduduk (X3) berkontribusi terhadap Penerimaan PPh 21 Badan sebesar 130006. Jika Jumlah Penduduk meningkat 1\% maka Penerimaan PPh 21 Badan meningkat sebesar 130006. Sebaliknya jika Jumlah Penduduk menurun 1\%, maka Penerimaan PPh 21 Badan menurun sebesar 130006. 


\section{Jurnal Riset Akuntansi dan Bisnis}

Vol 21 No.1 Tahun, 2021 hal 129 - 136

ISSN 1693-7597 (Print), 2623-2650 (online)

Available online: http://jurnal.umsu.ac.id/index.php/akuntan

5. Jika nilai variabel Jumlah Angkatan Kerja $(X 4)=1$ dengan asumsi variabel lainnya tetap atau bernilai 0 maka variabel Jumlah Angkatan Kerja (X4) berkontribusi terhadap Penerimaan PPh 21 Badan sebesar -2196334. Jika Jumlah Angkatan Kerja meningkat 1\% maka Penerimaan PPh 21 Badan menurun sebesar 2196334.

\section{Uji Simultan (Uji F)}

\section{Tabel Hasil Uji Simultan (Uji F)}

\begin{tabular}{|c|c|c|c|c|c|c|}
\hline \multicolumn{2}{|c|}{ Model } & $\begin{array}{l}\text { Sum of } \\
\text { Squares }\end{array}$ & df & Mean Square & $F$ & Sig. \\
\hline \multirow[t]{3}{*}{1} & Regression & $1,997 \mathrm{E}+21$ & 4 & $4,993 E+20$ & 95,605 & $.000^{\mathrm{b}}$ \\
\hline & Residual & $2,873 \mathrm{E}+20$ & 55 & $5,223 \mathrm{E}+18$ & & \\
\hline & Total & $2,285 \mathrm{E}+21$ & 59 & & & \\
\hline
\end{tabular}

Sumber: data olahan peneliti 2020

Berdasarkan tabel di atas, F hitung sebesar 95,6. Dimana nilai Fhitung >Ftabel yaitu 2,77 dan dilihat dari nilai probabilitas kurang dari tingkat signifikansi $(\leq 0,05)$. Artinya H0 ditolak dan menerima H1 yakni Jumlah Pemotong Pajak, PDRB, Jumlah Penduduk dan Jumlah Angkatan Kerja secara bersama sama berpengaruh terhadap Penerimaan PPh 21 Badan.

\section{Uji t (Uji Parsial)}

Nilai $\mathrm{T}$ tabel dapat dicari dengan signifikansi $0,05 / 2=0,025$ dengan $\mathrm{df}=55$. Maka diperoleh $\mathrm{t}_{\text {tabel }}$ sebesar 2,004.

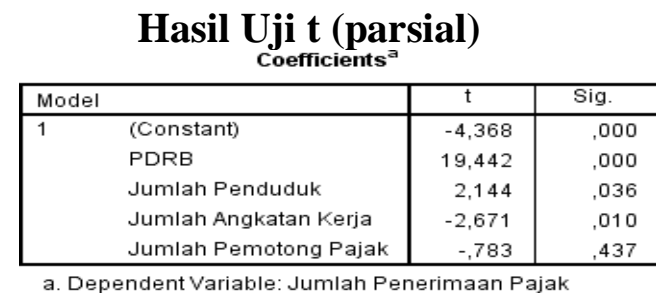

Sumber : SPSS, data diolah (2020)

menunjukkan nilai t-hitung variabel PDRB dan Jumlah Penduduk lebih besar dari nilai ttabel, artinya, tidak terdapat pengaruh yang signifikan untuk variabel PDRB dan Jumlah Penduduk terhadap jumlah penerimaan PPh Pasal 21 Badan pada Kantor Pelayanan Pajak Pratama Binjai. Sebaliknya nilai t-hitung variabel jumlah angkatan kerja dan jumlah pemotong pajak lebih kecil dari nilai t-tabel, artinya terdapat pengaruh yang signifikan antara variabel jumlah angkatan kerja dan jumlah pemotong pajak terhadap jumlah penerimaan PPh Pasal 21 Badan pada Kantor Pelayanan Pajak Pratama Binjai.

\section{PEMBAHASAN}

Pengaruh Jumlah Pemotong Pajak, Produk Domestik Regional Bruto (PDRB), Jumlah Angkatan Kerja dan Jumlah Penduduk secara bersama-sama berpengaruh terhadap penerimaan PPh pasal 21Badan di KPP Pratama Binjai. Hipotesis terakhir dalam penelitian ini yaitu pengaruh Jumlah Pemotong Pajak, Produk Domestik Regional Bruto (PDRB), 


\section{Jurnal Riset Akuntansi dan Bisnis}

Vol 21 No.1 Tahun, 2021 hal 129 - 136

ISSN 1693-7597 (Print), 2623-2650 (online)

Available online: http://jurnal.umsu.ac.id/index.php/akuntan

Jumlah Angkatan Kerja, dan Jumlah Penduduk berpengaruh secara bersama-sama terhadap penerimaan PPh pasal 21 Badan di KPP Pratama Binjai. Berdasarkan hasil uji hipotesis dengan uji $\mathrm{F}$, dimana $\mathrm{F}$ hitung sebesar 95,6. Jika dibandingkan dengan $\mathrm{F}$ tabel sebesar 2,77 pada taraf signifikan 5\%, maka $\mathrm{F}$ hitung $>\mathrm{F}$ tabel $(95,6>2,77)$, sehingga nilai tersebut signifikan.Berdasarkan perhitungan tersebut, maka disimpulkan bahwa Jumlah Pemotong Pajak, Produk Domestik Regional Bruto (PDRB), Jumlah Angkatan Kerja, dan Jumlah Penduduk berpengaruh secara bersama-sama terhadap penerimaan PPh pasal 21 Badan di KPP Pratama Binjai. Terdapatnya pengaruh secara bersama-sama antara Jumlah Pemotong Pajak, Produk Domestik Regional Bruto (PDRB), Jumlah Angkatan Kerja, dan Jumlah Penduduk terhadap penerimaan PPh pasal 21 Badan di KPP Pratama Binjai mengindikasikan bahwa penerimaan pajak dipengaruhi oleh ekonomi makro. Ekonomi makro sendiri meliputi Produk Domestik Regional Bruto (PDRB), Jumlah penduduk, investasi dan inflasi yang merupakan roda penggerak pada kegiatan perekonomian.Kegiatan ekonomi sendiri di kota Binjai sendiri lumayan tertata rapi. Di mana daerah perdagangan dan pusat perekonomian dan pusat pemerintahan berpusat di wilayah Pusat Kota. Sektor perdagangan dan jasa memberikan kontribusi paling besar dalam bidang perekonomian kota Binjai dibandingkan sektor lain. Kawasan perindustrian terletak di daerah Binjai Utara dan menjadi penyumbang kedua dalam roda perekonomian kota Binjai. Industri di kota Binjai sendiri masih tumbuh positif seperti industri pengolahan, pengadaan listrik dan gas, pengadaan air, pengolahan sampah, limbah dan daur ulang, serta kontruksi.Sedangkan bagian timur dan selatan sendiri merupakan daerah pertanian. Kota Binjai sendiri masih dikenal dengan pertaniannya dimana perkebunan rambutan yang luas di kota Binjai.

Perkebunan rambutan sendiri mampu menghasilkan kapasitas lebih dari 1000 ton per tahun. Hal ini sesuai dengan yang dikemukan oleh Purwiyanto dan Tity Hernawati (2002: 71), dimana tinggi rendahnya penerimaan pajak berkaitan dengan makro ekonomi seperti, pertumbuhan ekonomi, tingkat inflasi, jumlah penduduk, investasi, dan angkatan kerja. Hal ini terjadi karena variabel-variabel tersebut selain menjadi asumsi penting dalam menyusun kerangka kebijakan ekonomi termasuk sektor penerimaan perpajakan juga mempunyai pengaruh terhadap aktivitas kegiatan perekonomian. Todaro dan Smith (2006) menyebutkan secara lebih luas besarnya potensi pajak di suatu daerah ditentukan oleh faktor seperti tingkat pendapatan rill per kapita, tingkat ketimpangan distribusi pendapatan rill penduduk, kekokohan dari sektor-sektor perindustrian dalam perekonomian, keandalan dari jenis ekonomi yang berlangsung serta kemampuan kelembagaan dan aparat administrasi, khususnya dalam lembaga birokrasi pajak.

\section{KESIMPULAN}

Berdasarkan hasil penelitian ini dapat disimpulkan sebagai berikut:

1. Jumlah Pemotong Pajak berpengaruh negatif dan tidak signifikan terhadap Penerimaan $\mathrm{PPh} 21$ Badan. Bertambahnya jumlah pemotong pajak di Kota Binjai tidak mendukung adanya pertambahan penerimaan $\mathrm{PPh} 21$ karena kembali kepada kepatuhan wajib pajak badan dalam membayar kewajiban perpajakan terutama pada penyetoran pajak yang telah dipotong dan dipungut.

2. Produk Domestik Regional Bruto (PDRB) berpengaruh positif dan signifikan terhadap penerimaan PPh pasal 21 Badan. Terdapatnya pengaruh antara Produk Domestik Regional Bruto (PDRB) dan penerimaan PPh pasal 21 mengindikasikan bahwa jumlah penerimaan PPh pasal 21 dipengaruhi oleh Produk Domestik Regional Bruto 


\section{Jurnal Riset Akuntansi dan Bisnis}

Vol 21 No.1 Tahun, 2021 hal 129 - 136

ISSN 1693-7597 (Print), 2623-2650 (online)

Available online: http://jurnal.umsu.ac.id/index.php/akuntan

(PDRB). Hal ini dapat terjadi karena apabila pertumbuhan daerah tinggi maka pendapatan dan kesejahteraan masyarakat akan ikut meningkat. Tingginya nilai

3. Jumlah penduduk berpengaruh positif dan signifikan terhadap penerimaan $\mathrm{PPh}$ pasal 21 Badan. Terdapatnya pengaruh antara penduduk terhadap penerimaan $\mathrm{PPh} 21$ mengindikasikan bahwasanya penerimaan pajak penghasilan dipengaruhi oleh Jumlah Penduduk Kota Binjai. Dengan adanya pertumbuhan penduduk maka akan terjadi kenaikan konsumsi yang mengindikasikan juga bahwa adanya peningkatan pendapatan masyarakat.

4. Jumlah Angkatan Kerja berpengaruh negatif dan signifikan terhadap penerimaan $\mathrm{PPh}$ pasal 21 Badan. Apabila tenaga kerja mengalami peningkatan maka penerimaan $\mathrm{PPh}$ 21 juga akan mengalami penurunan. Kecendrungan hubungan negatif ini dapat diakibatkan karena tingkat penganguran yang tinggi.

5. Jumlah Pemotong Pajak, PDRB, Jumlah Penduduk dan Jumlah Angkatan Kerja secara bersama sama berpengaruh terhadap Penerimaan PPh 21 Badan. Tinggi rendahnya penerimaan pajak berkaitan dengan makro ekonomi seperti, pertumbuhan ekonomi, tingkat inflasi, jumlah penduduk, investasi, dan angkatan kerja. Hal ini terjadi karena variabel-variabel tersebut selain menjadi asumsi penting dalam menyusun kerangka kebijakan ekonomi serta sektor penerimaan perpajakan juga mempunyai pengaruh terhadap aktivitas kegiatan perekonomian.

\section{REFERENSI}

Badan Pusat Statistik Kota Binjai. 2020. Data dan Infomasi Penduduk Kota Binjai. Kota Binjai: BPS Kota Binjai

Dwi, Sunar Prasetyono. 2011. Buku Pintar Pajak. Yogyakarta: Laksana

Lembaga BPS dalam Statistik Indonesia (2013)

Mankiw, N. George. 2006. Pengantar Ekonomi Makro. Jakarta: Ghalia Indonesia

Muhammad Ikhsan Nasution (2017)

Musgrave, Richard A, Peggy B. 1989. Public Finane in Theory and Practise. New York : Graw Hill Book Compay

Asdora, Putri. 2014. "Pengaruh WP Badan Dan WP Orang Pribadi Terhadap Total Penerimaan Pajak Dengan Menggunakan Variabel Intervening Jumlah SPT Tahunan Badan, Jumlah SPT Masa PPN Dan Jumlah SPT Orang Pribadi”, Jurnal TEKUN, Fakultas Ekonomi Universitas Gunadarma, Vol. 05 No.01, Maret 2014

Rusli, Said. 2012. Pengantar Ilmu Kependudukan. Jakarta: LPES

Sugiyono. 2009. Metode Penelitian Kuantitatif Kualitatif. Bandung: Alfabeta

Suryadi. 2006. "Model Hubungan Kasual Kesadaran, Pelayanan, Kepatuhan Wajib Pajak Dan Pengaruhnya Terhadap Kinerja Penerimaan Pajak". Jurnal Keuangan Dan Publik. Program Pascasarjana Universitas Negeri Malang. Vol. 04 No.01, April 2006 Simanjutak, Timbul \& Imam Mukhlis. 2012. Dimensi Ekonomi Perpajakan dalam Pembangunan Ekonomi. Bogor: Penerbit Raih Asa Sukses 